\title{
AGO2 Gene
}

National Cancer Institute

\section{Source}

National Cancer Institute. AGO2 Gene. NCI Thesaurus. Code C84488.

This gene plays a role in RNA binding and catabolism. 